UJMR, Volume 5 Number 2, December, 2020, pp 138 - 147 ISSN: 2616 - 0668

https://doi.org/10.47430/ujmr.2052.019

Received: $12^{\text {th }}$ November, 2020

Accepted: $3^{\text {rd }}$ December, 2020

\title{
Sanitary Status and Occurrence of Some Water-Borne Pathogens in Well and Surface Waters of Panhauya Community and Ahmadu Bello University Farm, Zaria
}

\author{
${ }^{* 1}$ Afegbua, S. L., ${ }^{1}$ Abdulmumin, M.A., ${ }^{1}$ Tsoho, A.A., ${ }^{1}$ Fatihu, U. and ${ }^{1}$ Idris, I. \\ ${ }^{1}$ Department of Microbiology, Ahmadu Bello University, Zaria, Kaduna State, Nigeria \\ *Corresponding author: seniyat.larai@gmail.com; +2348141200810.
}

\begin{abstract}
The Sustainable Development Goal on sanitation aims to achieve universal access to good health, affordable drinking water, sanitation and an end to open defeacation by 2030. The recent ranking of Nigeria as first globally for open defecation is of public and environmental health concern. This study assessed the sanitary condition and the microbiological quality of well and surface waters of Panhauya community and Ahmadu Bello University farm, Zaria, and the antibiogram of the bacterial isolates.. Based on the WHO criteria, the sanitary inspection showed that $16.7 \%, 54.2 \%, 25 \%$ and $4.2 \%$ of the water sampling points had a very high, high, intermediate and low risk of contamination respectively. Occurrence of Escherichia coli, Giardia lamblia, Entamoeba histolytica, Pseudomonas aeruginosa, Salmonella spp and Vibrio cholerae in water samples from Panhuaya community was $87.5 \%, 75 \%, 68.8 \%, 50 \%, 25 \%$ and $12.5 \%$ respectively. In $\mathrm{ABU}$ farm Shika, the occurrence was; $E$. coli $(75 \%)$, E. histolytica (63\%), $G$. lamblia and Salmonella spp. All E. coli isolates exhibited high multidrug resistance to antibiotics screened with a MAR index of 0.3-0.8. The drinking water sources in Panhuaya and $A B U$ farm were unsafe and the presence of these pathogens in the water samples may be attributed to a number of factors including poor sanitation, manure application and open defecation practice. This indicates a public health risk to the residents and emphasises the need for safe water supplies sanitation and antibiotic stewardship.

Keywords: Well water; surface water; sanitary inspection; open defecation; water-borne pathogens; Zaria.
\end{abstract}

INTRODUCTION

Despite the efforts by the Sustainable Development Goal on sanitation to achieve access to good health, affordable drinking water, and an end to open defecation by 2030 , 892 million people in the world still practice open defecation (WHO 2018, Saleem et al., 2019).Poor drinking water sources such as wells and surface water are used by over 663 million people worldwide with most of them in SubSaharan Africa and Asia. Ten percent of the world's population is thought to consume food irrigated by waste water. Unsafe water supplies, open defecation, indiscriminate waste disposal and poor environmental sanitation are linked to the transmission of water-borne diseases (Squire and Ryan, 2017, WHO, 2018). The contamination of water sources is mainly attributed to pollution by on-site sanitation facilities such as pit latrines and defecation along boundaries of water sources (Okullo et al. 2017).

Although, improvements in sanitation have been recorded, open defecation remains a public health concern particularly in many developing countries (Okullo et al., 2017). The 2019 ranking of Nigeria as first globally for open defecation is of public and environmental health concern (Punch, 2019). In Nigeria, open defecation is practiced in rural and urban communities due to inadequate toilet facilities, poor standard of living and hygiene (Salaudeen, 2017). This may be linked to the high morbidity and mortality from water-borne diseases such as typhoid and cholera annually (WHO, 2018). Like many communities in Nigeria, the residents of Panhauya community of Giwa local government, Kaduna rely on well, surface water and sachet water occasionally. These water sources may be exposed to faecal contamination due to open defecation and poor sanitation. Hence, this study was carried out to assess the occurrence of some bacteria (Escherichia coli, Vibrio cholerae, Salmonella spp and Pseudomonas spp) and parasites (Giardia lamblia and Entameoba histolytica) in well and surface waters of Panhauya community and Ahmadu Bello University (ABU) farm Shika. 
UJMR, Volume 5 Number 2, December, 2020, pp 138 - $147 \quad$ ISSN: 2616 - 0668

The study objectives include; 1) to identify possible factors and sources of contamination of water sources in Panhauya community and $A B U$ farm, 2) to detect the presence of some selected bacteria and parasites in well and surface water samples in Panhauya community and $\mathrm{ABU}$ farm, and 3 ) to assess the antibiogram of the bacteria isolated from well and surface water samples.

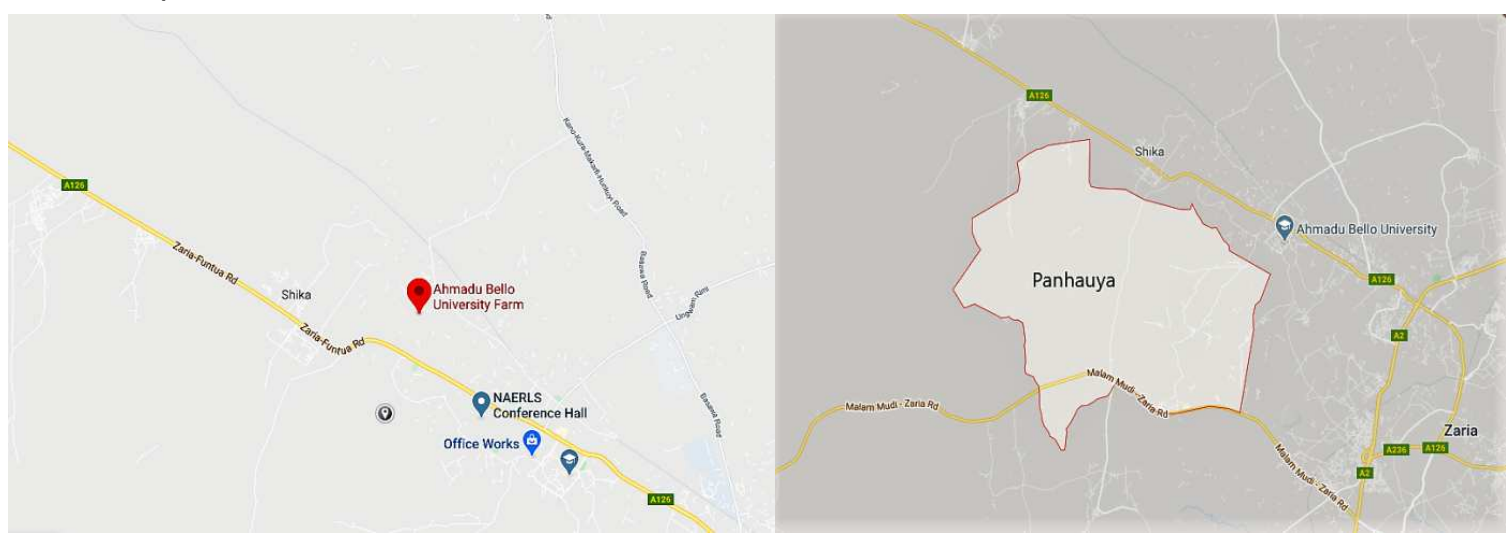

Figure 1: Maps showing Panhauya and Ahmadu Bello University Farm, Zaria (Taken from Google Maps).

Panhauya has the coordinate locations of $11^{\circ} 08^{\prime} 46.5^{\prime \prime} \mathrm{N}$ and $7^{\circ} 39 ' 26.7^{\prime \prime E}$. Panhauya community is a densely populated rural settlement located behind Phase II of $A B U$, Zaria. The agrarian community living in locally built mud houses. The community has one primary school located opposite the village head's house and a Primary health care centre. Their major source of drinking water is surface water, well water and occasionally sachet water. There is a surface water/river which flows from Shika environs and also flows into the $A B U$ dam; the major water source for the University community. The ABU farm Shika is located along the Zaria-Funtua road. It also has two wells and a river that serve as a source of drinking water to the animals and some locals. It also has a large dam containing an estimated capacity of $945,000 \mathrm{~m}^{3}$ of water which ensures all year-round water for fishing and irrigation (Schillhorn, 1979; Fatihu, 2016).

Questionnaire Administration and Sanitary survey

Questionnaire was designed and administered to gather information on how the waters get contaminated, what the water is used for, presence of domestic animals and the state of the wells in Panhauya community and $A B U$ farms. Questionnaires were administered to private well owners and to residents of houses nearest to the public wells which serve as a water source. The purpose of a sanitary survey was to evaluate and identify possible means by which water especially drinking water may become contaminated and rendered unsafe for

UMYU Journal of Microbiology Research

\section{MATERIALS AND METHODS}

Study Area

The study areas were Panhauya community and Ahmadu Bello University Farm at Shika Zaria both in Giwa Local Government of Kaduna state (Figure 1). human use (EPA, 2008). The surroundings of the wells and surface water in study areas were surveyed to determine contamination points and possible means by which the waters are contaminated. Each sampling point was surveyed for presence of gutters, drainage pipes, septic tanks and sediments/detritus, the fetcher used was examined while dry areas surrounding the surface water were surveyed for presence of animal dung and human faeces and any other source of contamination. A sanitary inspection was conducted with World Health Organisation (WHO) sanitary inspection forms in accordance with their guidelines. The sanitary inspection form consists of structured questions to be provided with a 'yes' or 'no' answers. Where "yes" answer score 1 point and indicate the presence of risk of contamination (ROC) while 'no' answers score 0 point and indicates a negligible risk. The total score or ROC score is interpreted as very high risk (9-11), high risk (6-8), intermediate risk (3$5)$ and low risk (0-2). A high ROC implies a greater risk that the drinking water is contaminated by the poor sanitary condition and faecal contamination around the water source. Sanitary inspection of all the water sources was conducted and followed by ROC calculation and interpretation (Okullo et al., 2017).

\section{Collection of Water Samples}

In Panhauya community, a total of 13 well water samples (5 private wells and 8 public wells) and 3 samples from the river (three 
UJMR, Volume 5 Number 2, December, 2020, pp 138 - 147 ISSN: 2616 - 0668

different points; PSW1, PSW2 and PSW3) were collected.

From Ahmadu Bello University Farm Shika, surface water samples were collected from the river (six different points; SSW1, SSW2, SSW3, SSW4, SSW5 and SSW6) and the two wells on the farm (one sample each) following approval of the farm manager. All samples were collected during the raining season between $8 \mathrm{am}$ and 10am. Sterile sample bottles were used to collect two litres of the well and surface water for the detection of Entamoeba histolytica and Giardia lamblia (Gyang et al., 2017). Another set of sterile $500 \mathrm{~mL}$ bottles was used to collect well and surface water samples for the isolation of bacteria. The samples were placed in ice cold packs and transported to the laboratory for analyses.

Analysis of Water Samples

Water quality assessment and isolation of Escherichia coli

The Most Probable Number (MPN) method was used to assess the water quality and the selective isolation of Escherichia coli (Cheesebrough, 2006).

\section{Isolation of Vibrio cholerae}

To isolate Vibrio cholerae from collected water sample, $3 \mathrm{ml}$ of each water sample was enriched in an equal volume of double strength Alkaline Peptone Water (APW) in a tube, the tube was incubated at $37^{\circ} \mathrm{C}$ for 6-8 hours. Thiosulfate Citrate Bile Salts (TCBS) agar was inoculated with a loopful of the enriched water sample and incubated at $37^{\circ} \mathrm{C}$ for 24 hours. The suspected colonies of Vibrio cholerae which produce yellow shiny colonies and were 2-3 mm in diameter on TCBS agar were subcultured onto Nutrient agar slants for further studies (Cheesbrough, 2006; Alam et al., 2014; Alam et al., 2015).

Isolation of Salmonella and Pseudomonas species

Pseudomonas aeruginosa and Salmonella spp were isolated by pre-enrichment method followed by inoculation onto a selective medium. About $1 \mathrm{ml}$ of each of the water samples was transferred onto $9 \mathrm{ml}$ lactose broth and swirled gently. Tubes prepared for the isolation of Pseudomonas aeruginosa and Salmonella spp were incubated at $37^{\circ} \mathrm{C}$ and $43^{\circ} \mathrm{C}$ (to enhance isolation) respectively. Aseptically, the broth cultures were subcultured on cetrimide agar (Pseudomonas isolation) and xylose-lysine-deoxycholate agar (Salmonella isolation) and incubated at $37^{\circ} \mathrm{C}$ for 24 hours. The pure isolates were maintained on Nutrient agar slants and kept in the refrigerator at $4^{\circ} \mathrm{C}$ for further laboratory investigations (Cheesbrough, 2006).
Biochemical characterization of bacterial isolates

Following Gram staining as described by Cheesbrough (2006), biochemical tests were conducted to characterize the different bacterial isolates. For Escherichia coli, the following tests were carried out indole test, Methyl Red-Voges Proskauer (MR-VP) test and Citrate utilization test. For Vibrio cholerae these included oxidase test, string test and sugar fermentation test on Kligler Iron Agar (KIA). Salmonella and Pseudomonas isolates were characterized with the indole test, MR-VP test, Citrate utilization test, urease and motility test, Triple Sugar Iron (TSI) test, Catalase test and Oxidase test (Cheesbrough 2006).

Antibiogram Assay

Antibiogram assay was carried out using disc diffusion method (Kirby Bauer technique) as described by the Clinical and Laboratory Standards Institute (CLSI) standard. For Escherichia coli, Pseudomonas aeruginosa and Salmonella spp, the following antibiotic discs

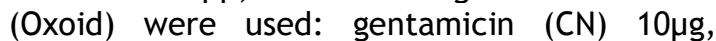

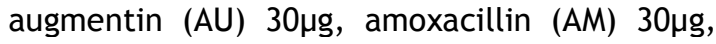
sparfloxacin (SP) 30 $\mu$, chloramphenicol (C)

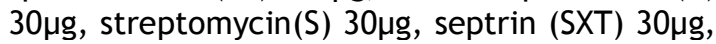

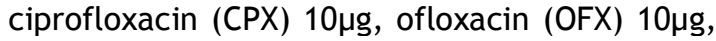

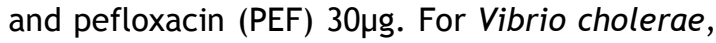
containing Chloramphenicol, Tetracycline and Trimethoprim-sulfamethoxazole/Cotrimoxazole (septrin) were used as recommended by the (CDC, 1999; Cheesbrough, 2006). Percentage antibiotic resistance (AR) of the isolates was calculated by dividing the number of antibiotics to which the isolates exhibited resistance divided by the number of antibiotics used for the antibiotic assay and expressed in percentage.

Detection of cyst of Entamoeba histolytica and Giardia lamblia

The water samples were analysed using the calcium carbonate flocculation method. Onelitre of the water sample was treated with 10 $\mathrm{mL}$ of Calcium Chloride solution and $10 \mathrm{~mL}$ of Sodium bicarbonate solution in a labelled beaker. The $\mathrm{pH}$ of the solution was adjusted to 10 by the addition of 10 to $15 \mathrm{~mL}$ Sodium Hydroxide solution depending on the initial $\mathrm{pH}$ of the water. The solution was mixed thoroughly using a glass stirrer and allowed to settle for a minimum of two hours at room temperature. The supernatant was carefully discarded and sediments dissolved by adding 20 $\mathrm{mL}$ of $10 \%$ weight/volume sulphuric acid. The dissolved sediments were centrifuged at $3000 /$ rpm for 15 minutes. 
UJMR, Volume 5 Number 2, December, 2020, pp 138 - 147 ISSN: 2616 - 0668

A drop of the sediment obtained after centrifugation was placed on clean grease free slide for wet mount observation after which a drop of Lugol's iodine was added to improve the contrast. It was covered with a cover slip and viewed under $\mathrm{x} 10$ and $\mathrm{x} 40$ objective lens. A coloured atlas was used in the identification of the parasite (Gyang et al., 2017; Omolade and Gbadamosi, 2017).

RESULTS

Household characteristics

With respect to the educational level of the respondents in 13 households with wells at Panhauya community, 7, 5 and 1 had primary, secondary and tertiary education. Only one out of the 13 households with wells treats the water by boiling or use of alum before drinking. All the households have pit latrines as the toilet facility but residents still practice OD especially while at their farms due to lack of toilet facilities.

Sanitary inspection

The survey revealed the sanitary condition of the wells sampled with potential impact on water quality (Table 1). Based on the WHO guidelines, a very high, high, intermediate and low risk of contamination was observed for $16.7 \%, 54.2 \%, 25 \%$ and $4.2 \%$ of the sampling points respectively.

Table 1: Potential contaminants around water sources and MPN index of water sampled from Panhauya community and ABU farm Shika.

\begin{tabular}{|c|c|c|c|c|c|c|}
\hline $\begin{array}{l}\text { Sampling } \\
\text { site }\end{array}$ & $\begin{array}{l}\text { Sampling } \\
\text { points }\end{array}$ & $\begin{array}{c}\text { No. of } \\
\text { contaminants } \\
\text { observed }\end{array}$ & $\begin{array}{c}\text { Sources of } \\
\text { Contamination } \\
\text { observed }\end{array}$ & $\begin{array}{c}\text { Distance between } \\
\text { contaminant and } \\
\text { sampling site (meters) }\end{array}$ & $\begin{array}{l}\text { MPN index } \\
\text { (per ml) }\end{array}$ & $\begin{array}{c}\text { ROC } \\
\text { score* }\end{array}$ \\
\hline \multirow[t]{16}{*}{ Panhauya } & PSW1 & 1 & Cow dung & 1 & $>11$ & 7 \\
\hline & PSW2 & 1 & Cow dung & 4 & $>11$ & 5 \\
\hline & PSW3 & 1 & Detritus & 5 & 11 & 5 \\
\hline & PuW1 & 3 & $\begin{array}{l}\text { Liquid waste, } \\
\text { detritus, algal } \\
\text { growth }\end{array}$ & 2 & 2.4 & 5 \\
\hline & PuW2 & 3 & $\begin{array}{l}\text { Sewage, liquid } \\
\text { waste, detritus }\end{array}$ & 1 & 1.5 & 7 \\
\hline & PuW3 & 3 & $\begin{array}{l}\text { Gutters, septic } \\
\text { tank, drainage }\end{array}$ & 2 & 1.5 & 4 \\
\hline & PuW4 & 3 & $\begin{array}{l}\text { Animal dung, } \\
\text { detritus, algal } \\
\text { growth }\end{array}$ & 2 & 0.15 & 9 \\
\hline & PuW5 & 2 & $\begin{array}{l}\text { Animal dung, } \\
\text { detritus }\end{array}$ & 1 & 1.5 & 2 \\
\hline & PuW6 & 2 & $\begin{array}{l}\text { Detritus, algal } \\
\text { growth }\end{array}$ & 1 & 0.15 & 7 \\
\hline & PuW7 & 2 & $\begin{array}{l}\text { Detritus, algal } \\
\text { growth }\end{array}$ & 1 & ND & 5 \\
\hline & PuW8 & 2 & $\begin{array}{l}\text { Animal dung, } \\
\text { detritus }\end{array}$ & 2 & 0.93 & 7 \\
\hline & PrW1 & 1 & Pit latrine & 10 & 4.6 & 6 \\
\hline & PrW2 & 3 & $\begin{array}{l}\text { Drainage, animal } \\
\text { dung, pit latrine }\end{array}$ & 4 & 0.93 & 10 \\
\hline & PrW3 & 2 & Detritus, pit latrine & 54 & ND & 8 \\
\hline & PrW4 & 2 & two pit latrines & 4 & 0.20 & 9 \\
\hline & PrW5 & 1 & Pit latrine & 10 & 11 & 3 \\
\hline \multirow[t]{8}{*}{$A B U$ farm } & FW1 & 3 & $\begin{array}{l}\text { Cow dung, detritus, } \\
\text { algal growth }\end{array}$ & 1 & 1.5 & 8 \\
\hline & FW2 & 3 & $\begin{array}{l}\text { Cow dung, detritus, } \\
\text { algal growth }\end{array}$ & 1 & 1.5 & 9 \\
\hline & SSW1 & 1 & Detritus & 2 & $>11$ & 8 \\
\hline & SSW2 & 1 & Detritus & 4 & $>11$ & 8 \\
\hline & SSW3 & 3 & $\begin{array}{l}\text { faeces, animal } \\
\text { dung, detritus }\end{array}$ & 1 & $>11$ & 8 \\
\hline & SSW4 & 2 & Detritus, cow dung & 2 & $>11$ & 8 \\
\hline & SSW5 & 3 & $\begin{array}{l}\text { faeces, detritus, } \\
\text { cow dung }\end{array}$ & 2 & $>11$ & 8 \\
\hline & SSW6 & 2 & Cow dung, detritus & 3 & $>11$ & 8 \\
\hline
\end{tabular}

FW: Farm well; ND: Not detected; PrW: private well; PSW: Panhauya Surface Water; PuW: public well; ROC: risk of contamination; SSW: Shika Surface Water; ${ }^{*}$ Contamination risk score: 9-11 very high; 6-8 high; 3-5 intermediate; 0-2 low. 
Microbiological quality of water samples and antibiogram assay

The MPN index was higher in the surface water samples compared to well water samples except that of one private well PrW5 with MPN index equal to those of the surface water at Panhauya (Table 1). With respect to the sampling sites, the occurrence of Escherichia coli and E. histolytica was higher $(100 \%)$ in the surface water samples compared to the well water samples. The two Vibrio cholerae isolated were from private wells in Panhauya community. The occurrence of Giardia lamblia, Salmonella spp and Pseudomonas aeruginosa were higher in the public wells $(25 \%)$ compared to the private wells $(12.5 \%)$ and surface water samples (12.5\%) in Panhauya (Table 2). The distribution of the bacteria and parasites with respect to some characteristics of the wells in Panhauya is presented in Table 3. Occurrence of Escherichia coli and Entamoeba histolytica were higher in surface water compared to those of the well water collected at ABU farm, Shika (Table 4). Amongst the bacteria isolated, all $E$. coli isolates exhibited higher multidrug resistance to antibiotics screened with a MAR index of 0.3-0.8 (Table 5 and 6). Augmentin and amoxacillin resistance was common to all the $E$. coli isolates (Tables 5 and 6).

Table 2: Occurrence of selected pathogens in well and surface water at Panhauya community, Zaria

\begin{tabular}{llllllll}
\hline Sampling site & $\begin{array}{l}\text { Total } \\
\text { No. of } \\
\text { samples }\end{array}$ & $E C$ & $V C$ & $P A$ & $\begin{array}{l}\text { Salmonella } \\
\text { spp }\end{array}$ & GL & EH \\
\hline Public wells & $\mathbf{8}(50 \%)$ & $7(87.5 \%)$ & 0 & $4(25 \%)$ & $2(12.5 \%)$ & $6(75 \%)$ & $5(62.5 \%)$ \\
Private wells & $5(31 \%)$ & $4(80 \%)$ & $2(40 \%)$ & $2(12.5 \%)$ & $1(6.25 \%)$ & $5(100 \%)$ & $3(60 \%)$ \\
Surface water & $3(19 \%)$ & $3(100 \%)$ & 0 & $2(12.5 \%)$ & $1(6.25 \%)$ & $1(33.3 \%)$ & $3(100 \%)$ \\
Total & $\mathbf{1 6}$ & $\mathbf{1 4}$ & $\mathbf{2}$ & $\mathbf{8 ( 5 0 \% )}$ & $\mathbf{4 ( 2 5 \% )}$ & $\mathbf{1 2 ( 7 5 \% )}$ & $\mathbf{1 1 ( 6 8 . 8 \% )}$ \\
& $(\mathbf{1 0 0 \% )}$ & $\mathbf{( 8 7 . 5 \% )}$ & $\mathbf{( 1 2 . 5 \% )}$ & & & & \\
\hline
\end{tabular}

Key: $\mathrm{EC}=E$. coli, $\mathrm{VC}=V$. cholerae, $\mathrm{PA}=P$. aeriginosa, $\mathrm{GL}=\mathrm{G}$. lamlia, $\mathrm{EH}=E$. histolytica

Table 3: Occurrence of selected pathogens with respect to characteristics of wells sampled at Panhauya community, Zaria.

\begin{tabular}{|c|c|c|c|c|c|c|c|c|}
\hline Factors & $\begin{array}{c}\text { Sub- } \\
\text { category }\end{array}$ & $\begin{array}{c}\text { No of } \\
\text { wells } \\
(n=13) \\
(\text { PrW }= \\
5) \\
\text { (PuW= } \\
8)\end{array}$ & $E C$ & $V C$ & $\begin{array}{l}\text { Salmonella } \\
\text { spp }\end{array}$ & $P A$ & $E H$ & $G L$ \\
\hline $\begin{array}{l}\text { Physical cover } \\
\text { of wells }\end{array}$ & $\begin{array}{c}\text { Covered } \\
\text { Uncovered }\end{array}$ & $\begin{array}{c}0 \\
13(100)\end{array}$ & $\begin{array}{c}2(15.4 \%) \\
11(84.6 \%)\end{array}$ & $\begin{array}{c}0 \\
2(100 \%)\end{array}$ & $\begin{array}{c}0 \\
3(100 \%)\end{array}$ & $\begin{array}{c}0 \\
6(100 \%)\end{array}$ & $\begin{array}{l}5(38.5 \%) \\
8(61.5 \%)\end{array}$ & $\begin{array}{c}0 \\
11(100 \%)\end{array}$ \\
\hline $\begin{array}{l}\text { Outer hygiene } \\
\text { of the well }\end{array}$ & $\begin{array}{l}\text { Clean } \\
\text { Unclean }\end{array}$ & $\begin{array}{c}3(23 \%) \\
10(77 \%)\end{array}$ & $\begin{array}{l}2(15.4 \%) \\
9(69.2 \%)\end{array}$ & $\begin{array}{l}1(50 \%) \\
1(50 \%)\end{array}$ & $\begin{array}{c}0 \\
3(100 \%)\end{array}$ & $\begin{array}{l}4(66.7 \%) \\
2(33.3 \%)\end{array}$ & $\begin{array}{l}2(15.4 \%) \\
7(53.8 \%)\end{array}$ & $\begin{array}{l}4(36 \%) \\
7(67 \%)\end{array}$ \\
\hline Casting & $\begin{array}{l}\text { Yes } \\
\text { No }\end{array}$ & $\begin{array}{l}7(54 \%) \\
6(46 \%)\end{array}$ & $\begin{array}{l}5(38.5 \%) \\
6(46.2 \%)\end{array}$ & $\begin{array}{c}2(100 \%) \\
0\end{array}$ & $\begin{array}{c}0 \\
3(100 \%)\end{array}$ & $\begin{array}{l}4(66.7 \%) \\
2(33.3 \%)\end{array}$ & $\begin{array}{l}3(23.1 \%) \\
5(38.5 \%)\end{array}$ & $\begin{array}{l}8(73 \%) \\
3(27 \%)\end{array}$ \\
\hline $\begin{array}{l}\text { Presence of } \\
\text { roaming animals }\end{array}$ & $\begin{array}{l}\text { Present } \\
\text { Absent }\end{array}$ & $\begin{array}{c}10(77 \%) \\
3(23 \%)\end{array}$ & $\begin{array}{l}9(69.2 \%) \\
2(15.4 \%)\end{array}$ & $\begin{array}{l}1(50 \%) \\
1(50 \%)\end{array}$ & $\begin{array}{l}2(66.7 \%) \\
1(33.3 \%)\end{array}$ & $\begin{array}{l}3(50 \%) \\
3(50 \%)\end{array}$ & $\begin{array}{l}6(46.2 \%) \\
2(15.4 \%)\end{array}$ & $\begin{array}{l}8(73 \%) \\
3(27 \%)\end{array}$ \\
\hline $\begin{array}{l}\text { Distance } \\
\text { between the } \\
\text { well and septic } \\
\text { tank/ Pit } \\
\text { latrine* }\end{array}$ & $\begin{array}{c}0-20 m \\
20-40 m\end{array}$ & $\begin{array}{l}4(80 \%) \\
1(20 \%)\end{array}$ & $\begin{array}{c}3(60 \%) \\
0\end{array}$ & $\begin{array}{c}2(100 \%) \\
0\end{array}$ & $\begin{array}{c}1(100 \%) \\
0\end{array}$ & $\begin{array}{l}1(50 \%) \\
1(50 \%)\end{array}$ & $\begin{array}{l}2(40 \%) \\
1(20 \%)\end{array}$ & $\begin{array}{l}4(80 \%) \\
1(20 \%)\end{array}$ \\
\hline $\begin{array}{l}\text { Topography of } \\
\text { septic tank/ Pit } \\
\text { latrine to well** }\end{array}$ & $\begin{array}{c}\text { Side- } \\
\text { stream } \\
\text { Up-stream }\end{array}$ & $\begin{array}{l}4(80 \%) \\
1(20 \%)\end{array}$ & $\begin{array}{l}3(60 \%) \\
1(20 \%)\end{array}$ & $\begin{array}{l}1(50 \%) \\
1(50 \%)\end{array}$ & $\begin{array}{c}1(100 \%) \\
0(0 \%)\end{array}$ & $\begin{array}{c}2(100 \%) \\
0(0 \%)\end{array}$ & $\begin{array}{c}2(40 \%) \\
0\end{array}$ & $\begin{array}{l}4(80 \%) \\
1(20 \%)\end{array}$ \\
\hline
\end{tabular}

Key: PrW = Private well; PuW = Public well * indicates data collected for PrW only

Key: $\mathrm{EC}=E$. coli, $\mathrm{VC}=V$. cholerae, $\mathrm{PA}=P$. aeriginosa, $\mathrm{GL}=G$. lamlia, $\mathrm{EH}=E$. histolytica 
UJMR, Volume 5 Number 2, December, 2020, pp 138 - $147 \quad$ ISSN: 2616 - 0668

Table 4: Occurrence of selected pathogens in well and surface waters at ABU farm, Shika

\begin{tabular}{llllll}
\hline Sampling site & $\begin{array}{l}\text { Total No. } \\
\text { of samples }\end{array}$ & $\begin{array}{l}\text { Escherichia } \\
\text { coli }\end{array}$ & Salmonella spp & $\begin{array}{l}\text { Entamoeba } \\
\text { histolytica }\end{array}$ & $\begin{array}{l}\text { Giardia } \\
\text { lamblia }\end{array}$ \\
\hline Well water & $2(25 \%)$ & $2(100 \%)$ & $2(25 \%)$ & $2(25 \%)$ & $1(50 \%)$ \\
Surface water & $6(75 \%)$ & $4(67 \%)$ & $2(25 \%)$ & $3(38 \%)$ & $3(50 \%)$ \\
Total & $8(100 \%)$ & $6(75 \%)$ & $4(50 \%)$ & $5(63 \%)$ & $4(50 \%)$ \\
\hline
\end{tabular}

Table 5: Antibiotic resistance profile of selected bacteria isolated from well and surface water samples collected from Panhauya community, Zaria.

\begin{tabular}{|c|c|c|c|c|}
\hline Bacteria & Source & $\begin{array}{c}\text { Antibiotic resistance } \\
\text { profile }\end{array}$ & AR (\%) & MAR index \\
\hline \multirow[t]{14}{*}{ E. coli } & PSW1 & $\mathrm{CPX}, \mathrm{AU}, \mathrm{AM}$ & $3(30)$ & 0.3 \\
\hline & PSW2 & $C P X, A U, A M, S P$ & $4(40)$ & 0.4 \\
\hline & PSW3 & $C P X, A U, A M$ & $3(30)$ & 0.3 \\
\hline & PuW1 & $C P X, A U, A M$ & $3(30)$ & 0.3 \\
\hline & PuW2 & OFX, CPX, AU, AM, SP & $5(50)$ & 0.5 \\
\hline & PuW3 & OFX, CPX, AU, AM, SP & $5(50)$ & 0.5 \\
\hline & PuW4 & CPX, AU, AM, SP & $4(40)$ & 0.4 \\
\hline & PuW5 & $\mathrm{CPX}, \mathrm{AU}, \mathrm{AM}, \mathrm{SP}$ & $4(40)$ & 0.4 \\
\hline & PuW6 & OFX, CPX, AU, AM, SP & $5(50)$ & 0.5 \\
\hline & PuW8 & CPX, AU, AM, SP & $4(40)$ & 0.4 \\
\hline & PrW1 & $\mathrm{CPX}, \mathrm{AU}, \mathrm{AM}, \mathrm{SP}$ & $4(40)$ & 0.4 \\
\hline & PrW2 & AU, SXT, AM & $3(30)$ & 0.3 \\
\hline & PrW4 & PEF, AU, AM, SP & $4(40)$ & 0.4 \\
\hline & PrW5 & PEF, AU, AM, SP & $4(40)$ & 0.4 \\
\hline \multirow[t]{2}{*}{ V. cholerae } & PrW2 & SXT & $1(33.3)$ & 0.33 \\
\hline & PrW4 & SXT & $1(33.3)$ & 0.33 \\
\hline \multirow[t]{8}{*}{ P. aeruginosa } & PSW2 & $S$ & $1(10)$ & 0.1 \\
\hline & PSW3 & S, SXT, AU, AM & $4(40)$ & 0.4 \\
\hline & PuW2 & $\mathrm{CN}$ & $1(10)$ & 0.1 \\
\hline & PuW4 & S & $1(10)$ & 0.1 \\
\hline & PuW5 & $\mathrm{CN}$ & $1(10)$ & 0.1 \\
\hline & PuW8 & $\mathrm{S}, \mathrm{SXT}, \mathrm{AU}, \mathrm{AM}$ & $4(40)$ & 0.4 \\
\hline & PrW1 & $\mathrm{CN}$ & $1(10)$ & 0.1 \\
\hline & PrW5 & $\mathrm{CN}, \mathrm{AU}, \mathrm{AM}$ & $3(30)$ & 0.3 \\
\hline \multirow[t]{4}{*}{ Salmonella spp } & SSW3 & $\mathrm{S}, \mathrm{CN}, \mathrm{PEF}, \mathrm{AM}$ & $4(40)$ & 0.4 \\
\hline & PuW2 & $\mathrm{AU}, \mathrm{AM}$ & $2(20)$ & 0.2 \\
\hline & PuW7 & $\mathrm{S}, \mathrm{PEF}, \mathrm{AU}, \mathrm{AM}$ & $4(40)$ & 0.4 \\
\hline & PrW4 & $\mathrm{CN}, \mathrm{AM}$ & $2(20)$ & 0.2 \\
\hline
\end{tabular}

AR: Antibiotic Resistance; MAR: Multiple Antibiotic Resistance; PrW: private well; PSW: Panhauya

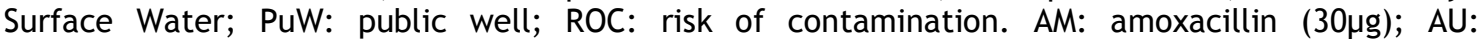
augmentin $(30 \mu \mathrm{g})$; C: Chloramphenicol $(30 \mu \mathrm{g})$; CN: gentamicin $(10 \mu \mathrm{g})$; CPX: ciprofloxacin $(10 \mu \mathrm{g})$;

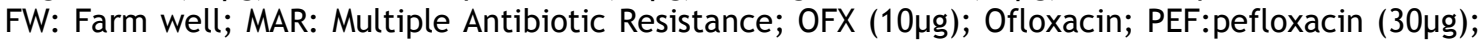

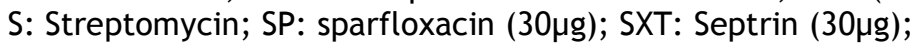


UJMR, Volume 5 Number 2, December, 2020, pp 138 - 147 ISSN: 2616 - 0668

Table 6: Antibiotic resistance profile of selected bacteria isolated from well and surface water samples collected from ABU farm Shika, Zaria.

\begin{tabular}{ccccc}
\hline Bacteria & Source & $\begin{array}{c}\text { Antibiotic resistance } \\
\text { profile }\end{array}$ & AR (\%) & MAR index \\
\hline E. coli & FW1 & SXT, AM, AU, PEF, OFX, S & $6(60)$ & 0.6 \\
& FW2 & SXT, CH, AM, AU, CN, OFX, & $7(70)$ & 0.7 \\
& SSW3 & SXT, CH, AM, AU, S & $5(50)$ & 0.5 \\
& SSW4 & SXT, CH, AM, AU, PEF & $5(50)$ & 0.5 \\
& SSW5 & SXT, AM, AU, PEF & $4(40)$ & 0.4 \\
Salmonella & SSW6 & SXT, CH, AM, AU, CN, PEF, & $8(80)$ & 0.8 \\
spp & SSW1 & OFX, S & $1(10)$ & 0.1 \\
& SSW2 & AM & $2(20)$ & 0.2 \\
& SSW3 & AU, AM & $1(10)$ & 0.1 \\
& SSW4 & AM & $1(10)$ & 0.1 \\
\hline
\end{tabular}

AR: Antibiotic Resistance; ROC: risk of contamination; FW: Farm well; MAR: Multiple Antibiotic

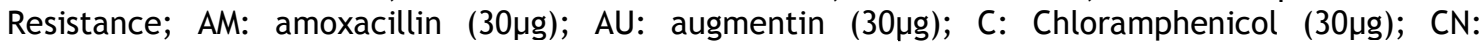

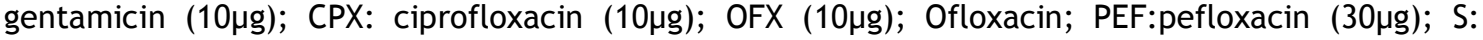

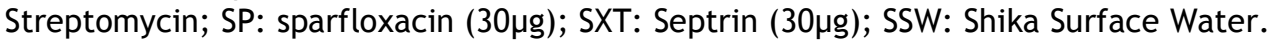

\section{DISCUSSION}

Sanitary survey of the sampling sites revealed a range of potential contaminants including human faeces and animal dung. Hence, these pose a high risk of contamination of the water source by different pathogens as shown by ROC scores. Occurrence of the selected pathogens in the water samples from Panhuaya community was in the order; Escherichia coli, Giardia lamblia, Entamoeba histolytica, Pseudomonas aeruginosa, Salmonella spp and Vibrio cholerae with $87.5 \%, 75 \%, 68.8 \%, 50 \%, 25 \%$ and $12.5 \%$ respectively. For $A B U$ farm Shika, the occurrence was in the order; $E$. coli $(75 \%), E$. histolytica (63\%), Giardia lamblia and Salmonella spp.

Previous studies have associated the presence of the contaminants such as faeces with the presence of pathogens in wells and surface water (Adagbada et al., 2012 and Taylor et al., 2015). Sanitary survey carried out by Fonseca et al. (2014) in Brazil and Okullo et al. (2017) in Kenya linked the presence of contaminants in the environment to the presence of waterborne pathogens in wells, streams and rivers. The occurrence rate of Escherichia coli in Panhauya (87.5\%) and ABU farms (75\%) is comparable to the $75 \%$ at Nkonkobe, South Africa and $99.3 \%$ in Northeast Georgia reported by Momba et al. (2006) and Cho et al. (2018) respectively. The occurrence of Vibrio cholerae $(12.5 \%)$ in this study differs from $2.4 \%$ reported by Bulus et al. (2015) but comparable to a $12.9 \%$ occurrence reported by Aryal et al. (2015). Bulus et al. (2015) study was carried out in Zaria, Nigeria while Aryal et al. (2015) study was carried out at Kathmandu Valley,
Nepal. The difference of occurrence between our findings and those of above-mentioned studies may be due to the difference in samples size, study area and nature of samples. The samples analysed in this study is less compared to 207 used by Bulus et al. (2015).

The high MAR index particularly for $E$. coli agrees with the findings of Olukosi et al., (2008) and Mishra et al., (2013). The antibiogram of the Vibrio cholerae isolates in this study corresponds to those of Miwande et al. (2015), Gupta et al. (2016) and Pal et al. (2018) which all reported a resistance of all Vibrio cholerae strains to Co-trimoxazole (septrin) while sensitivity for chloramphenicol and tetracycline slightly varied. The finding of sensitivity of the Vibrio cholerae isolates to chloramphenicol and tetracycline agreed with that of Gupta et al. (2016).

The occurrence of $75 \%$ observed for Giardia lamblia cyst in water samples from Panhauya differs from a $33.3 \%$ and $50 \%$ occurrence reported by Gyang et al. (2017) and Odikamnoro et al. (2014) respectively. However, the $50 \%$ occurrence of Giardia lamblia cyst in water samples from ABU Shika farm was different from the findings of Gyang et al. (2017) but agrees with that of Odikamnoro et al. (2014). Differences may be attributed to factors such as source of samples, sample size and study location as Gyang et al. (2017) study collected 60 samples from wells, streams, ponds and boreholes while Odikamnoro et al. (2014) collected 36 samples from wells, streams, ponds and boreholes, rain water and springs. 
UJMR, Volume 5 Number 2, December, 2020, pp 138 - 147 ISSN: 2616 - 0668

The studies by Odikamnoro et al. (2014) and Gyang et al. (2017) were carried out in Ohaukwu Local Government Area, Ebonyi state, Nigeria and Lafia Local Government Area Nassarawa state, Nigeria. A higher percentage of G. lamblia cyst in casted (73\%) wells at Panhauya than uncasted $(27 \%)$ wells corresponds to the finding of a $43.6 \%$ rate of $G$. lamblia cyst in casted wells and $25.8 \%$ for uncasted well by Bishop and Inabo (2015). Similarly, the occurrence of $E$. histolytica cysts was higher in wells with internal casting $(38.5 \%)$. Contrary to the study findings of Bishop and Inabo (2015), G. lamblia cysts were detected in all the wells irrespective of their distance from the septic tank/pit latrines.

The presence of the bacteria and parasite cysts in water bodies especially wells is multifactorial as factors such as distance of well to septic system, unhygienic surroundings, fetchers used, uncovered and uncasted wells may increase the likelihood of a well being contaminated. Furthermore, the presence of pathogens may be attributed to the presence of other sources of faecal contamination observed during the sanitary inspection as reflected by the ROC scores. A higher percentage of Giardia lamblia and E. histolytica cysts in wells with internal casting be attributed to some level of affinities of the cyst for the components of cement $\left(\mathrm{Ca}(\mathrm{OH})_{2}, \mathrm{CaO}, \mathrm{CaCO}_{3}\right)$ or improperly constructed casts (Bishop and Inabo, 2015). The presence of the parasites can also be attributed to poor construction of the wells which gives room for the influx of runoff waters carrying the parasitic organisms (Bishop and Inabo, 2015).

The MAR index of $>0.2$ observed for some of the isolates particularly for $E$. coli isolated from Panhauya community (0.3-0.8) and $A B U$ farm (0.4-0.8), indicates high risk contaminated source with frequent use of antibiotics. On the other hand, a low MAR index for Pseudomonas aeruginosa and Salmonella spp indicates lower antibiotic exposure to these organisms.

To the best of our knowledge, this is the first report on sanitary condition and the occurrence of water-borne pathogens (bacteria and parasites) in well and surface waters in Panhauya community and ABU Shika farm. The Calcium carbonate flocculation method used has a $72-77 \%$ recovery rate of Giardia lamblia cyst (Zarlenga and Trout, 2004) and may have

\section{REFERENCES}

Adagbada, O. A., Adesede, S., Nwaokorie, O. F., Niemogha, T. M. and Coker, O. A. (2012). Cholera epidemiology in Nigeria: an overview. The pan African medical journal 12:59. http: / / www.panafrican-

UMYU Journal of Microbiology Research affected our results. Due to limited resources, few samples were collected and the Salmonella isolates were not characterised to serotypes.

The sanitary condition of the water sources has serious implications as runoff can cause the water bodies present to get contaminated with faecal matter and hence, promote the spread of faecal-oral diseases such as cholera and giardiasis (Okullo et al. 2017). The prevalence of water-borne diseases including diarrhoea is higher in open defecation rural settings compared to those that are open defecationfree (Ayalewet al., 2018). According to WHO, all potable water should be free of any type of pathogenic organism (WHO, 2019). Hence, presence of these pathogens in the well and surface waters raises public health concerns particularly for the residents of Panhauya who use them as drinking water sources without proper treatment. This study emphasizes the public health risk the sanitary practice and water sources pose to the communities. There is need for potable water supply for these communities. Of importance is the creation of awareness on the need for sanitary practices (hand washing, waste disposal, use of proper toilet facilities) and proper antibiotic stewardship. Further surveillance studies and intervention will be needed in the study area as well as other communities to reduce the morbidity and mortality from a range of waterborne diseases.

\section{CONCLUSION}

The sanitary inspection of water sources in Panhauya community and $\mathrm{ABU}$ farm revealed the presence of different sources of contamination including faeces and sewage. Also, $16.7 \%, 54.2 \%, 25 \%$ and $4.2 \%$ of the water sampling points had a very high, high, intermediate and low risk of contamination respectively. Occurrence of Escherichia coli, Giardia lamblia, Entamoeba histolytica, Pseudomonas aeruginosa, Salmonella spp and Vibrio cholerae in water samples from Panhuaya community was $87.5 \%, 75 \%, 68.8 \%$, $50 \%, 25 \%$ and $12.5 \%$ respectively. For $A B U$ farm Shika, the occurrence was; $E$. coli $(75 \%)$, $E$. histolytica (63\%), G. lamblia and Salmonella spp. All E. coli isolates had a MAR index of 0.30.8 and exhibited higher multidrug resistance to antibiotics screened.

mejournal.com/content/articule/12/59 /full on 31/05/19.

Alam, M. T., Weppelmann, T. A., Weber, C. D., Johnson, J. A., Rashid, H. M., Birch, C. S., Brumback, B. A., DeRochars, V .M .B., Morris, J. G. and Ali, A. (2014). Monitoring Water Sources for www.ujmr.umyu.edu.ng 
UJMR, Volume 5 Number 2, December, 2020, pp 138 - 147 ISSN: 2616 - 0668

Environmental Reservoirs of Toxigenic Vibrio cholerae 01, Haiti. Emerging Infectious Diseases 20(3):356-363 retrieved from www.cdc.gov/eid on $31 / 05 / 19$

Alam, M. T., Weppelmann, T. A., Longini, I., DeRochars, V. M. B., Morris, J. G. and Ali, A. (2015). Increased Isolation Frequency of Toxigenic Vibrio cholerae 01 from Environmental Monitoring Sites in Haiti. PLoSONE 10(4):e0124098. doi:10.1371/journal.pone.0124098.

Aryal, S., Bhandari, S., Thapa, S., Karn, S. and Shrestha, S. (2015). Detection of Vibrio cholerae from Water Samples Collected from Different Areas of Kathmandu Valley, Nepal retrieved from www.eposters.net on 10/11/19.

Ayalew AM, Mekonnen WT, Abaya SW, Mekonnen ZA.(2018) Assessment of Diarrhea and Its Associated Factors in Under-Five Children among Open Defecation and Open Defecation-Free Rural Settings of Dangla District, Northwest Ethiopia. J Environ Public Health.;2018:4271915. . doi:10.1155/2018/4271915.

Bishop, H. G and Inabo, H. I (2015). "Effects of well casting, septic system distance and topography on Incidences of Giardia lambliaand Entamoebahistolyticain well of Samara-Zaria, Nigeria" Applied Research Journal 1(4), retrieved from www.civilica.com/paper-JR_ARJJR_ARJ-1-4_018 on 18/10/19.

Bulus, G. H., Ado, S. A., Yakubu, S. E. and Ella, E. E (2015). Isolation and Characterization of Vibrio cholerae from Water Sources in Zaria, Nigeria. Annals of Experimental Biology 3 (3):813 retrieved from www.aexpbio.comon 01/08/19.

Cheesbrough, M. (2006). District Laboratory Practice in Tropical Countries. Cambridge university press, New York ed.2: 36-38, 64-68, 100-102.

Fatihu, R. M. (2016). An Assessment of Relationship Between Particle Sizes and Organic Carbon of Soils in the Ahmadu Bello University Farm Shika - Zaria, Kaduna State. (Unpublished Undergraduate Project) Ahmadu Bello University, Zaria.

Fonseca, J. E., Carneiro, M., Pena, J. L., Colosimo, E. A., Silva, N. B., Costa, G. F. C. A., Moreira, E. L., Cairncross, S. and Heller, L. (2014). Reducing occurrence of Giardia duodenalis in children living in semiarid Regions: impact of a large scale rainwater harvesting initiative. Neglected

UMYU Journal of Microbiology Research
Tropical disease 8(6):e2943 retrieved from doi:10.1371/journal.pntd.0002943 on $17 / 11 / 19$

Gupta, P. K., Pant, N. D., Bhandari, R. And Shrestha, P. (2016). Cholera outbreak caused by drug resistant Vibrio cholera serogroup 01 biotype ElTor serotype Ogawa in Nepal; a cross-sectional study. Antimicrobial Resistance and Infection Control 5:23 retrieved from DOI $10.1186 / \mathrm{s} 13756-016-0122-7$ on $18 / 10 / 19$

Gyang, P. R., Uzoigwe, N. R., Ayim, J. O., Ombugadu, A. and Ahmed, $\mathrm{H}$. $O$. (2017). Evaluation of local drinking water sources to determine their possible contamination with parasite in lafia local government area nasarawa state, Nigeria. European Journal of Basic and Applied Sciences 4(1): 63-68 retrived from www.idpublications.org on $27 / 04 / 2020$

Mishra, M., Patel, A. K., Behera, N. (2013). Prevalence of Multidrug Resistant $E$. coli inthe river Mahanadi of Sambalpur. Curr. Res. Microbiol Biotechnology.1(5)239-244.

Momba M. N., Malakate V. K., Theron, J. (2006). Abundance of pathogenic Escherichia coli, Salmonella typhimurium and Vibrio cholerae in Nkonkobe drinking water sources. J Water Health. 4: 289-296.

Miwanda, B., Moore, S., Muyembe, J. J., Nguefack-Tsague, G., Kabangwa, I. K., Ndjakani, D. Y., Mutreja, A., Thomson, N., Thefenne, H., Garnotel, E., Tshapenda, G., Kakongo, D. K., Kalambayi, G. and Piarroux, R. (2015). Antimicrobial Drug Resistance of Vibrio cholerae, Democratic Republic of Congo, emerging infectious disease 12 (5):3-5 retrieved from www.cdc.gov/eid on 18/10/19.

Odikamnoro, O. O., Omowaye, O. S. andUduItuma, S. O. (2014). Parasitic Survey of Drinking Water Sources in Ohaukwu Local Government Area, Ebonyi State, Nigeria, European Journal of Nursing 1(1):1-5 retrieved from www.mcmed.us/journal/ejn on $18 / 10 / 19$

Okullo, O. J., Moturi, N. W. and Ogendi, M. G. (2017). open defection and its effect on the bacteriological quality of drinking water. Environmental Health Insights $11: 1-8$

Olukosi, O.M., Ameh, J.B. and Abdullahi, I.O. (2008); The prevalence of Escherichia coli 0157: $\mathrm{H7}$ in well water source in zaria metropolis, Kaduna State Nigeria. www.ujmr.umyu.edu.ng 
UJMR, Volume 5 Number 2, December, 2020, pp 138 - 147 ISSN: 2616 - 0668

Biological and Environmental
Sciences Journal for the Tropics, $5(4): 32-37$.

Omolade, O. O and Gbadamosi, Z. O. (2017).

"Parasitological Evaluation of Sachet Drinking Water in Areas of Lagos state, Nigera" Electronic journal of biology 13(2):144-151.

Punch, (2019) Open defecation: Nigeria ranks Number 1 in the World - Minister' (Punch, 28 October 2019), see https://punchng.com/opendefecation-nigeria-ranks-no-1-in-theworld-minister/

Salaudeen, H. A. (2017). "An Evaluation of the Communication Strategies Against Open Defecation in Sabon-Gari Local Government of Kaduna". Masters thesis submitted to the Department of Theatre And Performing Arts, A.B.U. Zaria.

Saleem, M., Burdett, T. and Heaslip, V.(2019) Health and social impacts of open defecation on women: a systematic review. BMC Public Health 19, 158. https://doi.org/10.1186/s12889-019$\underline{6423-z}$ and Ensink, H. J. J. (2015). The impact of Water Sanitation and Hygiene Interventions to control Cholera: A systematic Review, PLoS One 10(8):e0135676. doi: $10.1371 /$ journal.pone. 0135676 .

Squire, S. A and Ryan, U. (2017). "Cryptosporidumand Giardia in Africa: current and future challenges" retrieved from www.ncbi.nlm.nih.gov/pmc/articules/P MC5397716/ on 27/04/19

World Health Organization (WHO) (2018). sanitation retrieved from www. who.int/nes-room/factsheets/detail/sanitation on 30/04/19

World Health Organization (WHO) (2019). Cholera retrieved from www.who.int/nes-room/factsheets/detail/cholera on 23/09/19

Zarlenga, D. S. and Trout, J. M. (2004). Concentrating, purifying and detecting waterborne parasites, Veterinary Parasitology 126:195-217 retrieved from www.elsevier.com/locate/vetpar 